\title{
CORRIGENDUM
}

\section{Temperamental exuberance and executive function predict propensity for risk taking in childhood-CORRIGENDUM}

\author{
AYELET LAHAT,${ }^{a}$ KATHRYN A. DEGNAN,${ }^{a}$ LAUREN K. WHITE ${ }^{a}$ JENNIFER MARTIN MCDERMOTT, ${ }^{b}$ \\ HEATHER A. HENDERSON,${ }^{c}$ C. W. LEJUEZ, ${ }^{a}$ AND NATHAN A. FOX ${ }^{a}$ \\ ${ }^{a}$ University of Maryland, College Park; ${ }^{b}$ University of Massachusetts, Amherst; and ${ }^{c}$ University of Miami, Coral Gables
}

doi:10.1017/S0954579412000405, published by Cambridge University Press, 18 July 2012

There was an error in the Method Section (p. 850) in the description of the number of trials in the dimensional change card sort (DCCS) task, which is reprinted herein. The task included six preswitch cards (three blue trucks and three red stars) and six postswitch cards (three blue trucks and three red stars), which was reported as eight cards in the original paper. This error has no implications for the analysis or the reported results, because the data were presented as a percentage of correct trials passed by each participant. This percentage was calculated on the six trials. We regret these errors and any problems they may have caused.

\section{Reference}

Lahat, A., Degnan, K. A., White, L. K., McDermott, J. M., Henderson, H. A., et al. (2012). Temperamental exuberance and executive function predict propensity for risk taking in childhood. Development and Psychopathology, 24, 847-856.

In the first test phase (preswitch) participants were asked to sort six cards according to one dimension (e.g., color), and in the second testing phase (postswitch) they were asked to sort the cards again according to the other dimension (e.g., shape). 